\title{
Performatiwiteit en selfonthulling as sleutelbegrippe in Hannah Arendt se etiek van deugdelikheid
}

\author{
Marinus Schoeman \\ Departement Filosofie \\ Universiteit van Pretoria \\ 0002 Pretoria \\ mjschoem@postino.up.ac.za
}

\begin{abstract}
Performativity and self-revelation as key concepts in Hannah Arendt's ethic of virtue

The first three sections of this essay deal with certain aspects of Arendt's theory of action that are central to her idea of a truly ethical (i.e. virtuous) life. Considerable attention is given to her view of action as intrinsically self-revelatory and political, i.e. performative and dramaturgical. The self-revelatory and performative nature of action means that it should not be interpreted in expressivist terms. Nor should one judge it in terms of its utility or according to fixed religious or moral norms. Actions are to be judged solely in terms of their "greatness" or excellence, which for Arendt is akin to the virtuosity that one finds in the performing arts. The fourth section of the essay deals with the seemingly strong resemblance between Arendt's work and Richard Sennett's The Fall of Public Man (1976). The concluding section summarises Arendt's idea about an authentically ethical life and the kind of virtuousness that it implies.
\end{abstract}

\section{I}

Sonder twyfel kan aanvaar word dat Hannah Arendt (1906-1975) 'n waarlik etiese lewe, d.w.s. 'n goeie en gelukkige (gelukkende) lewe, primêr beskou as 'n lewe wat getuig van deugdelikheid in die sin van voortreflikheid en uitsonderlikheid. Voorts is dit alom bekend dat deugdelikheid vir Arendt ten nouste saamhang met handeling ("action"), wat volgens haar, streng onderskei moet word van arbeid ("labour") en werk ("work"). Handeling geskied, volgens Arendt, by uitstek in die politieke domein, in die openbare ruimte van die polis (Arendt, 1958:48-49, 55) as die ruimte waarin meningswisseling en oorlegpleging plaasvind, en waar persone hulleself in onderlinge wedywering deur unieke, uitsonderlike - grootse - dade van andere kan onderskei (Arendt, 1958:205-206). Agonisme (onderlinge stryd of wedywering) is inherent aan die handelinge wat binne die openbare (politieke) sfeer plaasvind (Arendt, 1958:41, 194; 1968:67). Hierdie handelinge vind nie slegs plaas in die openbare (politieke) ruimte nie; dit is ook konstitutief vir die openbare ruimte. Hierdie ruimte word in stand gehou deur gemeenskaplike handeling en spreke, nie soseer vir of teen andere nie, maar saam met andere (Arendt, 1958:180). Openbaarheid beteken om gesien en gehoor te word, om aan mekaar te verskyn, en as sodanig gaan dit elke formele politieke konstitusie vooraf. Vir Arendt is pluraliteit (die veelvuldigheid van verskillende perspektiewe) tegelyk die voorwaarde en die waarborg vir 'n gemeenskaplike werklikheid en wêreld (Arendt, 1958:50, 57). 
Die openbare of politieke sfeer is die sfeer van vryheid in dié sin dat dit by uitstek die sfeer van handeling is. Handeling, in teenstelling tot arbeid en werk/vervaardiging, is vir Arendt (soos vir die antieke Grieke) die hoogste uiting van die mens se aktiewe lewe (die vita activa). Die spesifieke kenmerk van handeling is, volgens Arendt "om inisiatief te neem", om iets nuuts te begin, waarby die akteurs altyd ook hulleself in woord en daad onthul (Arendt, 1958:177). In die handeling kom iemand se unieke persoonlikheid, waardeur hy homself van andere onderskei, tot openbaring. As selfonthulling en selfonderskeiding is die handeling egter nie op die self gerig nie, maar op die wêreld as gemeengoed van dinge en verhale. Die wêreld is ' $\mathrm{n}$ inter esse wat mense sowel met mekaar verbind as van mekaar skei (Arendt, 1958:52, 182).

Die selfonthulling waarvan daar in die handeling sprake is, moet nie verstaan word as ' $n$ ekspressie van ' $n$ voorafgegewe identiteit nie, want ' $n$ mens weet nie vooraf wie jy gaan onthul nie (Arendt, 1958:180, 192). ${ }^{1}$ Die onthulling kom onwillekeurig tot stand in alles wat jy doen. Dit is nie-intensioneel, en as sodanig het ' $n$ mens nooit volledig beheer daaroor nie. Arendt onderskei hierdie unieke, onvergelykbare "wie", wat in en deur die handeling onthul word, van die "wat" van "n mens se bestaan. Onder laasgenoemde verstaan sy daardie eienskappe, talente, of vermoëns wat een mens in gemeen kan hê met andere (Arendt, 1958:179-181). Ook motiewe en doelstellings is, hoe suiwer en onbaatsugtig ook al, nooit uniek nie (Arendt, 1958:206).

Handeling as selfonthulling het ' $n$ gebeure-karakter. Juis vanweë die nie-intensionele aard daarvan, is dit wesenlik episodies en transsubjektief. Dit is episodies in die sin dat dit ' $n$ vlugtige moment is in ' $n$ voortgaande proses van selfonthulling. Dit is transsubjektief omdat dit altyd tussen meerdere mense afspeel, en dus nooit eensydig deur ' $n$ enkele subjek toegeëien of manipuleer kan word nie:

In acting and speaking, men show who they are, reveal actively their unique personal identities and thus make their appearance in the human world ... This disclosure of "who" in contradistinction to "what" somebody is - his qualities, gifts, talents, and shortcomings which he may display or hide - is implicit in everything somebody says and does ... but its disclosure can almost never be achieved as a wilful purpose, as though one possessed and could dispose of this "who" in the same manner he has and can dispose of his qualities. On the contrary, it is more than likely that the "who," which appears so clearly and unmistakably to others, remains hidden from the person himself, like the daimon in Greek religion which accompanies each man throughout his life, always looking over his shoulder from behind and thus visible only to those he encounters. (Arendt, 1958:179-80)

Handelinge "produseer" 'n netwerk verhoudinge in die vorm van verhale (Arendt, 1958:181 e.v.). Verhale - wat op allerlei maniere bewaar bly en weer oorvertel kan

1 Villa (1996:92) lewer hieroor die volgende nuttige kommentaar: "The 'disclosure of the agent in speech and deeds' implies, for Arendt, the absence of an underlying subject; identity as something achieved rather than given; and the decentered nature of such self-revelation. Arendt stresses that the disclosure of the agent ... is nothing like a project. Intentionality has the most tenuous connection to the 'who' that action reveals. Nor is the disclosure of the agent in words and deeds a process that necessarily increases self-knowledge or brings one closer to self-transparency..." Vervolgens wys Villa hier op "n belangrike raakpunt met Nietzsche: "In the Preface to The Genealogy of Morals, he famously remarks that 'we men of knowledge are unknown to ourselves ... we are not "men of knowledge" with respect to ourselves.' If we substitute 'men of action' for 'men of knowledge' in the first phrase, we approach Arendt's position." 
word - is vir Arendt dan ook die mees oorspronklike uitkomste van handeling. Elke handeling is " $n$ ingryping in ' $n$ reeds bestaande netwerk verhale en bewerkstellig daarin iets nuuts. Omdat ook die mees doelbewuste handeling gepaard gaan met selfonthulling - Arendt identifiseer hierdie selfonthulling met vryheid - het die handeling altyd gevolge, wat die motiewe en doelstellings van die akteur te bowe gaan:

Freedom as related to politics is not a phenomenon of the will ... Action, to be free, must be free from motive on one side, from its intended goal as a predictable effect on the other. This is not to say that motives and aims are not important factors in every single act, but they are its determining factors, and action is free to the extent that it is able to transcend them. (Arendt, 1968:151; vgl. Arendt, 1958:205-206)

Vanweë die bestaande netwerk verhoudinge met sy vele botsende intensies bereik die handeling haas nooit sy doel nie. Daar is altyd ' $\mathrm{n}$ moment van onvoorspelbaarheid inherent aan die handeling, want die verhaal wat dit produseer is nooit volledig in sy greep nie (Arendt, 1958:191-92). Die handeling word opgeneem in 'n netwerk van tussenmenslike betrekkinge en produseer lewensgeskiedenisse, maar niemand is die outeur van sy lewensverhaal nie. ' $n$ Mens is veeleer ' $n$ akteur in die verhaal. En wat vir individuele lewensgeskiedenisse geld, geld ook vir dié van gemeenskappe:

The realm of human affairs, strictly speaking, consists of the web of human relationships which exists wherever men live together. The disclosure of the "who" through speech, and the setting of a new beginning through action, always fall into an already existing web where their immediate consequences can be felt. Together they start a new process which eventually emerges as the unique life story of the newcomer, affecting uniquely the life stories of all those with whom he comes into contact. It is because of this already existing web of human relationships, with its innumerable, conflicting wills and intentions, that action almost never achieves its purpose; but it is also because of this medium, in which action alone is real, that it "produces" stories with or without intention as naturally as fabrication produces tangible things ... Although everybody started his life by inserting himself into the human world through action and speech, nobody is the author or producer of his own life story. In other words, the stories, the results of his action and speech, reveal an agent, but this agent is not an author or producer. Somebody began it and is its subject in the twofold sense of the word, namely, its actor and sufferer, but nobody is its author. (Arendt, 1958:184-85; vgl. Arendt, 1958:232-33).

Die selfonthulling wat in en deur die handeling plaasvind, is tegelykertyd willekeurig en onwillekeurig. Daar gebeur altyd iets wat die akteur nie voorsien het nie, iets waardeur hy verras word. Dit is omdat sy handelinge altyd gesitueerd is binne ' $\mathrm{n}$ reeds bestaande konteks - "n wêreld wat hy met ander akteurs deel, en wat hy nie op "n soewereine manier kan "maak" of aan homself kan toeëien deur welke kragsinspanning van sy wil of denke ook al nie. In hierdie onmag van sy wil en denke setel egter juis die moontlikheid van sy vryheid: "Juis omdat ek myself nie gemaak het nie, is ek vry" (Arendt, 1994 vol. I:184). Die akteur moet sy "individuele psigologie" - die sfeer van intimiteit, van innerlike gevoelens, van goeie (of slegte) bedoelings en intensies - transendeer (Arendt, 1968:151) en homself "verloor" in die kontingensie, die onvoorspel- 
baarheid van die wêreld van politieke handeling saam met ander. ${ }^{2}$ Vryheid is paradoksaal te vinde in die prysgawe van die self en sy outonomie, en vryheid is die raison d'être van die politiek (Arendt, 1968:146). ${ }^{3}$

\section{II}

Vir Arendt is die waarde of doel van outentieke, deugdelike handeling geleë in die handeling self. ' $n$ Deugdelike handeling is geen middel tot een of ander eksterne doel nie. Gevolglik moet dit nie in terme van sy nuttigheidswaarde beoordeel word nie, en ewe min behoort dit onderwerp te word aan godsdienstige en morele maatstawwe wat vreemd is aan die aard en wese van die handeling (die politieke sfeer) self. Menslike gedrag, wat die lokus is van motiewe en gevolge, kan en moet gemeet word aan morele maatstawwe. Handelinge daarenteen, word uitsluitlik beoordeel in terme van hulle grootsheid, al dan nie:

Unlike human behavior - which the Greeks, like all civilized people, judged according to "moral standards," taking into account motives and intentions on the one hand and aims and consequences on the other - action can be judged only by the criterion of greatness because it is in its nature to break through the commonly accepted and reach into the extraordinary, where whatever is true in common and everyday life no longer applies because everything that exists is unique and sui generis ... The art of politics teaches men how to bring forth what is great and radiant - ta megala kai lampra, in the words of Democritus; as long as the polis is there to inspire men to dare the extraordinary, all things are safe; if it perishes, everything is lost. Motives and aims, no matter how pure or grandiose, are never unique; like psychological qualities, they are typical, characteristic of different types of persons. Greatness, therefore, or the specific meaning of its deed, can lie only in the performance itself and neither in its motivation nor its achievement. (Arendt, 1958:205-6)

In teenstelling tot gedrag, moet politieke handeling beskou word as performatief en a-teleologies van aard. As sodanig, kan dit waarskynlik beter verstaan word na analogie van estetiese voorwerpe, oftewel kunswerke. Arendt is bekend daarvoor dat sy ewe veel waarde toeken aan groot kuns as aan outentieke politiek. Weliswaar het politieke dade geen objektiewe bestaan soos kunswerke (letterkunde en die beeldende kunste) nie, en moet eerder na analogie van die uitvoerende kunste verstaan word (Arendt, 1968:153). Die grootsheid of deugdelikheid van ' $n$ politieke handeling bring Arendt in verband met die begrip van virtuositeit, wat slegs in die uitvoering daarvan geaktualiseer kan word, en dan ook slegs in die teenwoordigheid van meerdere persone ('n gehoor, ander spelers of deelnemers, ensovoort):

"[V]irtuosity" ... is an excellence we attribute to the performing arts (as distinguished from the creative arts of making), where the accomplishment lies in the performance itself and not in an end product which outlasts the activity that brought it into existence and becomes independent of it ... Since all acting contains an element of virtuosity, and because virtuosity is the excellence we ascribe to the performing arts, politics has often been defined as an art... Performing artists - dancers, play-actors, musicians, and the like - need an audience to

2 Vir ' $n$ mooi verduideliking van hierdie aspek van Arendt se denke, sien Honig (1993: 78-79).

3 Vir ' $n$ uitgebreide behandeling van Arendt se vryheidsbegrip, sien Schoeman (2004: 128 e.v.). 
show their virtuosity, just as acting men need the presence of others before whom they can appear; both need a publicly organized space for their "work," and both depend on others for the performance itself. Such a space of appearances is not to be taken for granted wherever men live together in a community. The Greek polis once was precisely that "form of government" which provided men with a space of appearances where they could act, with a kind of theatre where freedom could appear. (Arendt 1968: 153-54) ${ }^{4}$

Die begrip van virtuositeit hou verband met virtù (Latyn: virtus), 'n term wat Arendt (soos ook Nietzsche, en heel waarskynlik deur hom beïnvloed) oorneem by Machiavelli, en wat sy definieer as "the excellence with which man answers the opportunities the world opens up before him in the guise of fortuna" (Arendt, 1968:153). Virtù bring sy ook, soos ons reeds gesien het, in verband met virtuositeit (voortreflike spel) op die gebied van die uitvoerende kunste. Arendt voeg egter by dat laasgenoemde maar ' $n$ "feeble echo" is van die virtù van politieke handeling, wat onvergelykbaar is in grootsheid en glorie (Arendt, 1958:207). ${ }^{5}$

Die deugdelikheid of virtuositeit waarvan hier sprake is moet egter nie verwar word met selfekspressie nie. Arendt het geen geduld met die idee van "selfekspressie" nie nóg in die sfeer van handeling, nóg in dié van die kunste (Arendt, 1958:323). " $\mathrm{n}$ Handeling is, soos enige artistieke skepping, geen "uitvloeisel" van iets innerliks nie, maar ' $n$ onsekere inisiatief in ' $n$ vooraf bestaande en grootliks onvoorspelbare wêreld. Wanneer hy handel, ondergaan beide die akteur self en die wêreld waarin hy handel ' $\mathrm{n}$ verandering. In sy handeling toon die akteur aan homself en aan die ander dat hy meer is as wat hy van homself geweet of selfs vermoed het. Dit wat hy van homself onthul, oortref die verwagtinge, en juis in hierdie moment van verrassing en onvoorspelbaarheid lê die moontlikheid vir voortreflike (grootse en uitsonderlike) dade. Anders gestel: sonder fortuna kan daar geen deugdelikheid wees nie (Arendt, 1968:137).

Die moment van onwillekeurigheid word, volgens Arendt, implisiet erken in die mo-

4 Arendt het groot bewondering vir die antieke Grieke se performatiewe (dramaturgiese) opvatting van handeling en deugdelikheid. Sien ook byvoorbeeld Arendt (1978:-I 131) waar sy die volgende opmerk: "[H]uman virtue, the kalon k'agathon, was assessed neither as an innate quality or intention of the actor, nor by the consequences of his deeds - only by the performance, by how he appeared while he was doing; virtue was what we would call virtuosity. As with the arts, human deeds had to 'shine by their intrinsic merits,' to use an expression of Machiavelli's. Whatever exists was supposed, first of all, to be a spectacle fit for the gods, in which, naturally, men, those poor relations of the Olympians, wished to have their share."

5 Vgl. in hierdie verband die voortreflike hoofstuk van Dana Villa, "Theatricality and the Public Realm", in Villa (1999:128-54).

6 Vir 'n goeie beskrywing van die ekspressivisme, sien Taylor (1975, p. 16-50). Vir 'n goeie insig in Arendt se anti-ekspressivisme, sien Villa (1999, hoofstukke 5 en 6). Villa toon oortuigend aan dat "Arendt's appeal to theatrical metaphors in her discussions of political action and the public realm is, in fact, intended to demolish the presuppositions of the expressivist model of action" (p. 137). Hiermee weerlê hy die mening van skrywers soos Passerin d'Entrèves en Benhabib dat Arendt 'n "romantiese", ekspressivistiese beskouing van handeling het. Meer nog: hy toon dat kontemporêre voorstanders van 'n agonistiese politiek ("radikale demokrasie"), met name Sheldon Wolin, Bonnie Honig en William Connolly, se kritiek teen Arendt juis motiveer word deur 'n vorm van ekspressivisme, met die gevolg dat hulle heeltemal mistas aan die kern van Arendt se filosofie (sien veral p. 120-23). Villa kom tot die volgende slotsom: "Arendt's agonist critics have uniformly ignored the worldly thrust of her theatrical model of political action, of action as performance. Without exception, they dismiss her conception of the public sphere as a theatrical space where such (distanced, impersonal) freedom can dwell, the better to bring agonistic action in line with some version of the expressivist model." 
derne idee dat 'n egte kunswerk voortkom uit die kunstenaar se "creative genius", wat sy omskryf as "those features by which the artist transcends his skill and workmanship in a way similar to the way each person's uniqueness transcends the sum total of his qualities" (Arendt, 1958:210). Hierdie genialiteit, soos die "wie" wat in 'n outentieke handeling onthul word, kan nie vasgevang word nie: "it manifests the identity of a person and therefore serves to identify authorship, but it remains mute itself and escapes us if we try to interpret it as the mirror of a living person" (Arendt, 1958:211). Arendt beklemtoon voortduerend dat voortreflikheid - op die gebied van die kuns, soos ook in die sfeer van politieke handeling - nie in terme van 'n produksionistiese logika of intensionaliteit begryp kan word nie. Sy verduidelik dit, met ' $n$ aanhaling uit een van Isak Dinesen se verhale, soos volg:

It is an indispensable element of human pride to believe that who somebody is transcends in greatness and importance anything he can do and produce. "Let physicians and confectioners and the servants of the great houses be judged by what they have done, and even by what they have meant to do; the great people themselves are judged by what they are." Only the vulgar will condescend to derive their pride from what they have done; they will, by this condescension, become the "slaves and prisoners" of their own faculties and will find out, should anything more be left in them than sheer stupid vanity, that to be one's own slave and prisoner is no less bitter and perhaps even more shameful than to be the servant of somebody else ... The saving grace of all really great gifts is that the persons who bear their burden remain superior to what they have done, at least as long as the source of creativity is alive; for this source springs indeed from who they are and remains outside the actual work process as well as independent of what they may achieve. (Arendt, 1958:211)

\section{III}

Die selfonthulling wat plaasvind in die politieke handeling het egter ook ' $\mathrm{n}$ keerkant: iedere onthulling is tegelykertyd ook ' $\mathrm{n}$ verberging. Arendt stel die politieke akteur voor as iemand wat vele dinge verberg, ten einde meer te kan onthul. Soos in die antieke teater dra hy ' $n$ masker. In die antieke teater, het die masker die akteur se gesig verberg, maar sy eie stem laat deurklink. Arendt verwys na die Romeinse begrip persona, wat oorspronklik iets soos masker beteken het, en later oordragtelik die betekenis gekry het van ' $\mathrm{n}$ politieke en juridiese persoonlikheid (draer van regte en verpligtinge), wat die politieke domein aan elke burger toegeskryf het, en waarsonder elkeen slegs op sy naakte, ongevormde, natuurlike self aangewese sou wees:

The profound meaningfulness inherent in the many metaphors derived from the theatre is perhaps best illustrated by the history of the Latin word persona. In its original meaning, it signified the mask ancient actors used to wear in a play. (The dramatis personae corresponded to the Greek ta tou dramatos prosopa.) The mask as such obviously had two functions: it had to hide, or rather to replace, the actor's own face and countenance, but in a way that would make it possible for his voice to sound through. At any rate, it was in this twofold understanding of mask through which a voice sounds that the word persona became a metaphor and was carried from the language of the theatre into legal terminology. The distinction between a private individual in Rome and a Roman citizen was that the latter had a persona, a legal personality, as we would 
say; it was as though the law had affixed to him the part he was expected to play on the public scene, with the provision, however, that his own voice would be able to sound through. The point was that "it is not the natural Ego which enters a court of law. It is a right-and-duty-bearing person, created by the law, which appears before the law." Without his persona, there would be an individual without rights and duties, perhaps a "natural man" - that is, a human being or homo in the original meaning of the word, indicating someone outside the range of the law and the body politic of the citizens, as for instance a slave - but certainly a politically irrelevant being. (Arendt, 1973a:106-07)

In hierdie passasie sien ons tipies die skerp skeidslyn wat Arendt tussen die openbare en die private sfeer trek. Slegs in politieke handeling, d.w.s. in die openbare sfeer, kan daar selfonthulling plaasvind. Alleen hier is daar lig; in die ander sfere van die mens se bestaan heers daar duisternis. In sy nie-politieke lewe is die mens gereduseer tot sy biologiese spesie-bestaan, of tot die stereotipe gestaltes van sosiale gedrag, of tot ' $n$ verlore stryd om ' $n$ amorfe persoonlikheid te handhaaf teen alle sosiale druk. Daar is geen "ware" of outentieke self, apart van die politieke self, soos hy in die openbaar verskyn of presenteer word nie. Die ware self kan slegs ' $n$ politiek-gedefinieerde self wees; hy kan nie opgesoek word in die oneindige moontlikhede van sy innerlike prosesse of uitwendige reaksies nie. Kateb (1984:8-9) lewer hierop die volgende treffende kommentaar: "Political action is the great definer and concentrator of the self, the great stimulus to the formation of a self out of its own welter. Political action introduces coherence into the self and its experience. Such coherence is redemptive. Narrative, dramatic, or poetic art perfects the coherence ... Arendt thus drives her thesis of the real self as the worldly self very hard. Her contrast between the inner chaos and the shining world is never more acute than when she writes of the revelatory powers of political action. It is almost as if she welcomed the discipline of political action (when rightly done) as an excluder of most of the content of the human heart and mind."

Vervolgens wil ek nader ingaan op wat presies Arendt bedoel met hierdie vorming en dissiplinering wat die self in politieke handeling ondergaan. Om te handel in die openbare sfeer, beteken om ' $n$ bepaalde vorm aan te neem, soos die masker wat ' $n$ akteur opsit of die rol (persona) wat hy aanneem in 'n drama-opvoering. Om 'n masker te dra of " $\mathrm{n}$ bepaalde persona aan te neem, impliseer vir Arendt nie noodwendig om skynheilig of onopreg te wees nie. Inteendeel, sonder 'n masker of volgehoue rol-identiteit kan daar volgens Arendt geen sprake wees van opregtheid nie. Die ongemaskerde gesig is die onbeskermde (ongehude) self, uitgelewer aan selfbeheptheid en selfverterende passies soos haat en woede. Die skynheilige of onopregte mens, aan die ander kant, is iemand wat, indien hy ontmasker sou word, niks agter sy masker het om te openbaar nie: hy is ' $n$ kompulsiewe rolspeler, verander gedurig van een rol na ' $n$ ander, veins ' $n$ bepaalde rol-identiteit sonder om homself ooit daarmee te vereenselwig (alhoewel hy meestal onbewus is daarvan en homself wysmaak dat hy inderdaad is wat hy momenteel voorgee om te wees).

Om ' $\mathrm{n}$ masker te dra, is volgens Arendt om 'n bepaalde persona, 'n rol, 'n posisie, 'n publieke identiteit, vol te hou. Kateb (1984:10-11) vat Arendt se gedagtegang soos

7 Arendt verwys hier na E. Baker se "Introduction" tot sy vertaling van Otto Gierke, Natural Law and the Theory of Society 1500 to 1800, Cambridge, 1950. 
volg saam: "It is not a distortion of Arendt's meaning to say that she believes that it is the highest responsibility of the citizen to protect his mask so that in the artificial composure of his appearance the truth of his words may sound ... The distractions of personal idiosyncrasy, the hopeless struggle to keep on remembering who one truly is, and the impossibility of having an identity without having a public identity and of having a public identity without having a publicly defined identification all conduce to the view that the public action of a persona, a person masked, is one of the great sources of a kind of truthfulness in the world ... Wearing a mask or playing a role in political life, however, is a deliberate adoption of a commitment to consistency in the face of unforseeable events. It is not life lived in imitation of natural process. At the same time, Arendt ultimately believes that 'what one really is' cannot be played at: It does not preexist the role. The point is to choose a role knowingly and accept its discipline freely. The best role is that of the citizen. And to play a role in public life is to do more than play."

Die selfonthulling wat in die openbare sfeer plaasvind het duidelik ' $n$ formele, onpersoonlike karakter. Dit is nie soseer die akteur self wat onthul word nie, as eerder die "waarheid" wat in die gegewe omstandighede vereis word, of paslik is. Die waarheid wat hier tot openbaring kom is altyd relatief tot ' $n$ spesifieke konteks. Dit is ' $n$ konteks-relevante waarheid. Dit is geen universele of tydlose waarheid nie, en nog minder is dit die waarheid van blote inligting en kommunikasie. Waarheid moet hier in ' $\mathrm{n}$ retoriese sin verstaan word; dit gaan oor die kuns van die oorreding, oor "finding the right words at the right moment" (Arendt, 1958:26). "n Samelewing wat toegewy is aan die politieke lewe sal noodwendig ook toegewy wees aan die kuns van openbare redevoering en debat. ${ }^{9}$

Politieke handeling gee aan die akteur die geleentheid om te ontsnap aan die greep van sy eie subjektiwiteit, sy innerlike of "naakte" self. Daarin kom die spesifiek menslike vermoë om vry te wees tot openbaring. Die akteur neem ' $n$ bepaalde rol aan; hy leef hom op ' $n$ unieke en skeppende (verbeeldingryke) manier in die rol in. Hy vertolk en speel die rol ooreenkomstig sy opvatting van wat die rol vereis. Sodoende stileer hy (gee hy vorm aan) homself, en transendeer die psigiese determinismes en die chaos van sy innerlike self. Kateb (1984:12) maak hieroor die volgende opmerking: "He thus illuminates existence by redeeming some bit of life from the determinisms of the psyche. The revelation of this generic human capacity is, I think Arendt thought, the most profound existential achievement of political action."

IV

In een van Villa se verdienstelikste bydraes oor Arendt (Villa, 1999: Hoofstuk 6 "Theatricality and the Public Realm") toon hy aan dat haar werk 'n sterk ooreenkoms toon met Richard Sennett se The Fall of Public Man (1976), en dat ons trouens 'n veel beter insig in Arendt se werk kan kry wanneer ons dit met dié van Sennett vergelyk. Soos Arendt, maar heeltemal onafhanklik van haar, vestig ook Sennett die aandag op die teatrale aard van die openbare sfeer. Tot so laat as die $18 \mathrm{de}$ eeu, het die tradisie van die theatrum mundi gegeld; die samelewing is verstaan na analogie van die teater

8 Die relevante teksgedeelte hier is Arendt (1973a:98-109).

9 "To be political, to live in a polis, meant that everything was decided through words and persuasion and not through force and violence. In Greek self-understanding, to force people by violence, to command rather than persuade, were pre-political ways to deal with people characteristic of life outside the polis..." (Arendt, 1958:26-27). 
of verhoog, en dit het ruimte geskep vir " $n$ "impersonal sociability". Wat dit alles beteken, word mooi saamgevat deur Villa (1999:148):

Urban life in the eighteenth century built a "bridge" between the stage and the street, transferring a set of theatrical conventions and criteria of judgment (of dress, utterance, and believability) to the "theatre" of the city. To move in the public space of the eighteenth-century city was, almost by definition, to be an actor, a performer. A shared set of conventions governed the presentation of self and emotion to strangers, enabling the growth of an "impersonal sociability" distinctive to the time. These conventions (of gesture, dress and speech) opened a communicative space that worked by creating a distance between the actor and his acts or appearances. Within this conventionally defined space, judgment and understanding focused on the act, the gesture, the world, rather than the agent behind them. If the "world is a stage," then "character of acts and the character of actors are separate, so that a man of the world can censure an imperfection, or even a vice, without rage against the guilty party." When the common sense of public life was theatrical in this sense, one could disagree with the position held by another (often to the point of comical, polemical excess) without feeling the need to demonize the person of the opponent. One's opponent was simply an individual who had undertaken an evil or blameworthy role. In sum, it was the role that was condemned, not the person's nature.

Dit staan in skelle kontras tot die hedendaagse samelewing wat gekenmerk word deur " $n$ volslae verlies aan " $n$ "secular public culture" en deur die heerskappy van wat Sennett noem "an ideology of intimacy". Ek haal hier slegs enkele grepe aan uit Hoofstuk 11 van Sennett se fassinerende boek:

The reigning belief today is that closeness between persons is a moral good. The reigning aspiration today is to develop individual personality through experiences of closeness and warmth with others. The reigning myth today is that the evils of society can all be understood as evils of impersonality, alienation, and coldness. The sum of these three is an ideology of intimacy: social relationships of all kinds are real, believable, and authentic the closer they approach the inner psychological concerns of each person. This ideology transmutes political categories into psychological categories. This ideology of intimacy defines the humanitarian spirit of a society without gods: warmth is our god. The history of the rise and fall of public culture at the very least calls this humanitarian spirit into question ... Is it human to form soft selves in a hard world? (Sennett, 1976:259, 260)

Die hedendaagse samelewing word voorts gekenmerk deur "a systematic encouragement of narcissistic absorbtion by centering social transactions on an obsession with motivation. The self no longer concerns man as actor or man as maker; it is a self composed of intentions and possibilities ... now what matters is not what you have done but how you feel about it" (Ibid.) ${ }^{10}$ Die verregaande verpsigologisering en sentimenta-

10 "Being good is feeling good". Dit is die cliché waarvolgens die tipies narcissistiese individu van die laat-moderne samelewing sy lewe lei, aldus Christopher Lasch (sien Lasch, 1980). Vgl. ook Herman De Dijn (1993 \& 1999) se opmerkings oor sentimentalisme, MacIntyre (1981) oor emotivisme, en Bellah (1985) oor utilistiese en ekspressivistiese individualisme. 
lisering van die self en sy identiteit het 'n groot letsel op die samelewing en individue gelaat:

How is society injured by the blanket measurement of social reality in psychological terms? It is robbed of its civility. How is the self injured by estrangement from a meaningful impersonal life? It is robbed of the expression of certain creative powers which require a milieu at a distance from the self for their realization. Thus the intimate society makes of the individual an actor deprived of an art ... It is difficult to speak of civility in modern life without appearing to be a snob or a reactionary. The oldest meaning of the term connects "civility" with the duties of citizenship; today "civility" means either knowing which years of Cos-d'Estournel to decant or refraining from noisy and unseemly political demonstrations. To recover that obsolete meaning of civility and relate it to the frame of public life, I would define civility as follows: it is the activity which protects people from each other and yet allows them to enjoy each other's company. Wearing a mask is the essence of civility. Masks permit pure sociability, detached from the circumstances of power, malaise, and private feelings of those who wear them. Civility has as its aim the shielding of others from being burdened with oneself. (ibid.:264) ${ }^{11}$

Sennett toon aan dat die metaforiek van die teater en die konvensionaliteit ("impersonal sociability") wat indertyd gegeld het vanaf omstreeks 1750, veral onder die invloed van Rousseau, toenemend verdag gemaak en veroordeel is as "onmenslik" en anti-egalitêr, en dit is waarom die hedendaagse mens " $n$ "actor without the art of playacting" geword het.

In the theatre, there is a correlation between belief in the persona of the actor and belief in conventions. Play, playacting, and acting, all require belief in conventions to be expressive. Convention is itself the single most expressive tool of public life. But in an age wherein intimate relations determine what shall be believable, conventions, artifices, and rules appear only to get in the way of revealing oneself to another; they are obstructions to intimate expression. As the imbalance between public and intimate life has grown greater, people have become less expressive. With an emphasis on psychological authenticity, people become inartistic in daily life because they are unable to tap the fundamental creative strength of the actor, the ability to play with and invest feeling in external images of the self. Thus we arrive at the hypothesis that theatricality has a special, hostile relation to intimacy; theatricality has an equally special relation to a strong public life. (Sennett, 1976:37)

Die opkoms van ' $n$ kultuur van intimiteit beteken die ondergang van sosiale toneelmatigheid ("theatricality"); die ondergang van sosiale toneelmatigheid beteken die onder-

11 Sien ook Sennett se treffende opmerkings oor die belangrike kultuurfunksie van spel en van rituele in die menslike bestaan. Oor die ritueel sê hy die volgende: "Ritual is not self-expression; it is participation in expressive action whose meaning ultimately steps beyond immediate social life and connects with the timeless truths of the gods." Ook in 'n sekulêre samelewing is dit volgens Sennett onontbeerlik vir mense om uitdrukkingsmiddele soos rituele ter beskikking te hê: "contriving expression at a distance from the self; not expressing themselves, but, rather, being expressive..." Die hedendaagse mens is gestroop van sodanige ekspressiemiddele: "Expression is made contingent upon authentic feeling, but one is always plunged into the narcissistic problem of never being able to crystallize what is authentic in one's feelings." (Sennett, 1976:266-67) 
gang van die openbare lewe. Politieke akteurs tree steeds op in die openbaar, maar wat hulle opvoer is hulle intiem-persoonlike karakter, hulle gevoelens, die krag van hulle persoonlike oortuigings. Daarmee het ons die era betree van die kultus-persoonlikhede, die charismatiese figure wat hulle gehore probeer beïndruk "by superimposing private upon public imagery." Villa som dit soos volg op:

Sennett argues that this shift comes to light in the revolutions of 1848 , when virtuosos of Romantic subjectivity like Lamartine challenged and pacified hostile street audiences through the sheer force of their personality and charisma. Distrustful of conventions, such audiences became passive spectators, convinced that what the truth of what any public speaker had to say reduced, finally, to the kind of person he was. The more adept at performing "genuine" emotion - at displaying the private self in public - the politician is, the more believable he becomes. As Sennett remarks with regard to Lamartine: "The hidden power of a speaker like Lamartine is that he harnesses mystification. He has no text, and so escapes being measured by any standard of truth or reality. He can make the quality of his intentions and sentiments a self-sufficient basis of his legitimacy to rule..." While the age of both proletarian revolution and the Romantic performer may be over, this distinctive cognitive structure survives. For us, as for the revolutionaries of 1848, "a believable public event is created by a believable public person rather than a believable action ... The genuine aesthetic qualities of the meeting of politics and the arts having disappeared, what remains is only the obscurantist, paralyzing effect of a 'politics of personality'." (Villa, 1999:150; vgl. Sennett, 1976:25, 237)

\section{V}

Arendt is ook, net soos Sennett, oortuig daarvan dat die verregaande psigologisering en sentimentalisering wat in die openbare lewe ingetree het, rampspoedige gevolge het. Elders het ek hierdie kwessie uitvoerig bespreek, ${ }^{12}$ veral met verwysing na Arendt se kritiek op Rousseau en Robespierre. Hier wil ek egter die aandag vestig op 'n ander (weliswaar verbandhoudende) aspek van haar filosofie, naamlik haar beskouing oor die rol van "beginsels" in die politiek.

Om die onpersoonlike, nie-subjektivistiese aard van politieke handeling te beklemtoon, introduseer Arendt in die essay "What is Freedom?" (in Arendt, 1968) die begrip acting from a principle - in onderskeid tot aktiwiteite bepaal deur doelwitte of motiewe. Sy maak die volgende stelling (ek het vroeër reeds daarna verwys): "Action, to be free, must be free from motive on the one side, from its intended goal as a predictable effect on the other" (Arendt, 1968:151). Motiewe en oogmerke is weliswaar altyd teenwoordig, maar " $n$ handeling is vry "to the extent that it is able to transcend them." In "n effens gewysigde vorm, formuleer sy dit soos volg: "Action insofar as it is free is neither under the guidance of the intellect nor under the dictate of the will - although it needs both for the execution of any particular goal" (Arendt, 1968:152). Arendt wil die definisie van politieke handeling probeer suiwer van enige vorm van innerlike bestemming, of dit nou dié is van die wil, of van die berekenende intellek, die vurige hartsbegeerte, of die behoeftes van die liggaam of die gees. Egte politieke handeling is "onpersoonlik" in die sin dat dit handeling vanuit " $n$ beginsel is. Wat is " $n$ beginsel?

12 Sien Schoeman (2004: hoofstuk 7). 
Vir Arendt is dit hoegenaamd geen morele beginsel in die normale sin van die woord nie. Sy formuleer dit soos volg:

Principles do not operate from within the self as motives do ... but inspire, as it were, from without; and they are much too general to prescribe particular goals, although every particular aim can be judged in the light of its principle once the act has been started. For, unlike the judgment of the intellect which precedes action, and unlike the command of the will which initiates it, the inspiring principle becomes fully manifest only in the performing act itself ... In distinction from its goal, the principle of an action can be repeated time and again, it is inexhaustible, and in distinction from its motive, the validity of a principle is universal, it is not bound to any particular person or to any particular group. However, the manifestation of principles comes about only through action, they are manifest in the world as long as the action lasts, but no longer. (Arendt, 1968:152)

Arendt gee die volgende voorbeelde van sodanige beginsels: "honor or glory, love of equality, which Montesquieu called virtue, or distinction or excellence - the Greek aei aristeuein ('always strive to do your best and to be the best of all'), but also fear or distrust or hatred" (Ibid.). In "n ander essay, maak sy melding van "such political principles as freedom, justice, honor, and courage" (Arendt, 1968:243). In The Human Condition ( $\$ 33$ en 34) gee sy ' $n$ uitvoerige behandeling van die handelingsimmanente beginsels van vergewing ("forgiving") en belofte ("promising"), wat volgens haar die sine qua non is van " $\mathrm{n}$ waarlik deugdelike lewe. ${ }^{13}$

Om ooreenkomstig ' $\mathrm{n}$ beginsel te handel, beteken nie slegs om daardeur geïnspireer te wees nie, maar ook om dit te manifesteer. Dit gaan vir 'n politieke akteur nie om die najaging van byvoorbeeld eer of aansien nie; veel eerder doen hy alles wat hy doen op ' $\mathrm{n}$ eerbare manier, of hy verrig eerbare handelinge. Net so is dit ook met vryheid gesteld: "the appearance of freedom, like the manifestation of principles, coincides with the performing act. Men are free - as distinguished from their possessing the gift for freedom - as long as they act, neither before nor after; for to be free and to act are the same." (Arendt, 1968:152-53)

Om te leef in getrouheid en toewyding aan ' $n$ beginsel is om nie die self en sy eie belang voorop te stel nie. Dit is om vry te wees van die dwingende noodsaak van liggaamlike en psigiese behoeftes en begeertes. Politieke handeling openbaar die grootste van alle menslike vermoëns: die vermoë om weer (vir 'n tweede keer) gebore te word, die vermoë om te leef vir die wêreld en nie vir jouself nie. Vir Arendt kom dit treffend tot uitdrukking in Machiavelli se uitspraak "I love my native city more than my own soul". Hierop lewer sy soos volg kommentaar: "Most of Machiavelli's arguments against religion are directed against those who love themselves, namely their own salvation, more than the world; they are not directed against those who really love God more than they love either the world or themselves" (Arendt, 1973a:286).

\section{VI}

Ten slotte moet nogmaals gewys word op die radikale skeidslyn wat Arendt trek tussen die etiese dimensie van die menslike bestaan (wat vir haar saamval met handeling in die openbare of politieke domein) en omtrent enigiets anders in die hemel

13 Vir 'n uitgebreide bespreking van hierdie twee beginsels en die fundamentele rol wat dit speel in Arendt se etiek van die deug, sien Hoofstuk 6 (die slotafdeling) van my boek (Schoeman, 2004:174-181). 
en op die aarde. 'n Waarlik etiese (deugdelike) lewe is slegs moontlik binne die openbare, oftewel politieke, sfeer. En hierdie sfeer is vir haar die afgesonderde ruimte, soortgelyk aan die verhoog van 'n drama-opvoering, waar akteurs aan mekaar en aan hulle gehoor verskyn in die gestalte van 'n bepaalde persona of ' $n$ rol, welke rol elke akteur dan met die grootste mate van virtuositeit en oortuigingskrag probeer vertolk. Die deugdelikheid wat hier op die spel is, is 'n deugdelikheid in terme van outonome politieke beginsels, wat hoegenaamd niks in gemeen het met die mens se natuurlike behoeftes of sy morele en godsdienstige oortuigings of sentimente nie. Soos by die uitvoerende kunste is die bron van deugdelikheid wat sig manifesteer in politieke handeling, d.w.s. in uitsonderlike dade en woorde, suiwer die wil om te "speel" - om op te tree, 'n uitvoering te gee, 'n persona vol te hou, of deur 'n beginsel geïnspireer en daaraan lojaal te wees. Dit kan egter slegs 'n werklikheid word wanneer dit gepaard gaan met die (intellektuele) deug van goeie oordeel, waarop ek nie hier verder kan ingaan nie. ${ }^{14}$

\section{English summary}

The first three sections of this essay deal with certain aspects of Arendt's theory of action that are central to her idea of a truly ethical (i.e. virtuous) life. Action, as opposed to labour and work, is for Arendt (similar to the ancient Greeks) the highest expression of man's active life (the vita activa). The specific nature of action is to initiate or to begin something new, whereby the actor at the same time also reveals himself in words and deeds. In performing an action, one's unique personality, which distinguishes him from others, becomes manifest. As self-revelation and self-distinction action is, however, not focused on the self, but rather on the world of things and stories that one has in common with other people. The world is an inter esse that relates and separates men at the same time. This self-revelation should not be viewed as an expression of a prior identity, because nobody knows beforehand whom he or she is going to reveal. Self-revelation occurs involuntarily and unintentionally, and thus one never has total control over it. Arendt sharply distinguishes the unique, inexchangeable "who" which is revealed in action from the "what" of one's existence, comprising all those characteristics, talents, or competences that one may have in common with others. Every single action forms part of an existing web of human relationships and as such plays a more or less significant role in producing life histories. However, nobody can claim to be the author of his or her history; one is much rather an actor along with other actors in a story that is always open to contingent and unexpected events. Thus the status of the actor is one of non-sovereignty, which for Arendt is the hallmark of his freedom. This freedom can, however, only become a reality insofar as the actor succeeds in transcending his "individual psychology" - the realm of intimacy, of inner emotions, sentiments and intentions - and "loses" himself in the contingency and unpredictability of the world of political action along with his fellow human beings. Freedom resides paradoxically in the loss of the self and its autonomy, and freedom is the raison d'être of politics and a truly human life.

For Arendt the value or purpose of an authentic, virtuous action lies in the action itself. A virtuous action is not a means to some or other external purpose. Thus it should not be measured in terms of its utility, and even less in terms of

14 Sien my taamlik uitvoerige bespreking van Arendt se beskouings oor "goeie oordeel" en hoe dit saamhang met phronesis (insig), goeie smaak en ' $\mathrm{n}$ verfynde common sense in Schoeman (2004:167-174) 
religious or moral norms that are alien to the realm of action and politics. Human behaviour, which is governed by motives and consequences, can and ought to be judged by moral criteria. Actions, on the other hand, are judged solely in terms of their greatness or excellence. As opposed to behaviour, political action should be viewed as performative and a-teleological by nature, and as such one can understand them better in analogy to aesthetic objects or works of art, particularly the performing arts. Arendt relates the greatness or excellence of a political action with the notion of virtuosity, which becomes manifest only in its performance and thus only in the presence of other persons - an audience, other players or actors, etc. Virtuosity relates to virtù (Latin: virtus), a term that Arendt (like Nietzsche, and probably influenced by him) borrows from Machiavelli, defining it as "the excellence with which man answers the opportunities the world opens up before him in the guise of fortuna". Virtù also denotes virtuosity (excellence) in the realm of the performing arts. This virtuosity or excellence must not, however, be confused with self-expression. Like any artistic creation, an action is no "emanation" of something from within the artist or actor, but rather an uncertain initiative in an already existing and mostly unpredictable world. Whenever he acts, both the actor himself and the world in which he acts are transformed. That which he reveals of himself supersedes the expectations, and precisely in this moment of surprise and unpredictability lies the possibility for virtuosic (great and excellent) deeds. In other words, without fortuna there can be no virtue.

The self-revelation that occurs in political action, however, also has its opposite side: Each act of revelation is simultaneously also an act of concealment. Arendt sees the political actor as someone who conceals many things in order to reveal more. As in the theatre of the ancient world, he wears a mask. In ancient drama the mask concealed the actor's face, yet it still allowed his own voice to sound through. Arendt refers to the Roman word persona, which originally meant the same as mask and later on obtained the figurative meaning of the juridico- political personhood (bearer of rights and responsibilities) accorded to citizens of the polity, and without which the individual was thrown back on his own naked, unformed, natural self.

For Arendt, there is no such thing as a "true" or authentic self apart from the political self as it appears or presents itself in the public world. The true self can only be a politically defined self; it is not to be sought in the infinite possibilities of its internal psychic processes or external reactions. Kateb saliently summarises Arendt's position in this regard: "Political action is the great definer and concentrator of the self, the great stimulus to the formation of a self out of its own welter. Political action introduces coherence into the self and its experience. Such coherence is redemptive. Narrative, dramatic, or poetic art perfects the coherence ... Arendt thus drives her thesis of the real self as the worldly self very hard. Her contrast between the inner chaos and the shining world is never more acute than when she writes of the revelatory powers of political action. It is almost as if she welcomed the discipline of political action (when rightly done) as an excluder of most of the content of the human heart and mind."

To wear a mask is, for Arendt, to sustain a specific persona, a role, a position, or a public identity. It is probably not a distortion of Arendt's meaning to say that she believes it is the highest responsibility of the citizen to protect his mask, so that in the ar- 
tificial composure of his appearance, the truth of his words may sound. The distractions of personal idiosyncrasy, the hopeless struggle to keep on remembering who one truly is, and the impossibility of having an identity without having a public identity (and of having a public identity without having a publicly defined identification) all conduce the view that the public action of a persona, a person masked, is one of the great sources of a kind of truthfulness in the world. Wearing a mask or playing a role in political life, however, is a deliberate adoption of a commitment to consistency in the face of unforeseeable events. It is not a life lived in imitation of a natural process. At the same time, Arendt ultimately believes that "what one really is" cannot be played at: It does not pre-exist the role. The point is to choose a role knowingly and accept its discipline freely. The best role is that of the citizen. And to play a role in public life is to do more than play.

Political action gives the actor the chance to escape from the grip of his own subjectivity; his "inner" or "naked" self. Thus the specifically human capacity to be free manifests itself. The actor freely adopts a specific role, and plays it to the best of his ability, thereby giving style to himself and transcending the psychic determinisms and chaos of his inner self. He thus illuminates existence by redeeming some part of life from the determinisms of the natural, pre-political self. The revelation of this generic human capacity, is for Arendt, the most profound existential achievement of political action.

Section 4 of the essay deals with the seemingly strong resemblance between Arendt's work and Richard Sennett's The Fall of Public Man (1976). It is argued that one can indeed gain a better understanding of Arendt's work when one compares it with that of Sennett. The concluding section once more highlights the radical distinction that Arendt makes between the ethical dimension of human existence (which coincides with action in the public sphere) and virtually anything else in heaven and on earth. An authentically ethical (virtuous) life is only possible within the public or political realm. And this realm is for Arendt the isolated space, like the stage of a drama performance, where actors appear before each other and before an audience in the form of a specific persona or role, which they try to enact with as much virtuosity and credibility as possible. The virtuousness manifested here is a virtuousness in terms of autonomous political principles that have nothing whatsoever to do with man's natural needs or his moral and religious beliefs or sentiments. As in the performing arts, virtue springs purely from the will to "play" - to perform, to sustain a persona, or to be inspired by a principle and to remain loyal to it.

\section{Bibliografie}

Arendt, H. 1958. The Human Condition. Chicago: Univ. of Chicago Press

Arendt, H. 1965. Eichmann in Jerusalem. A Report on the Banality of Evil. New York: Viking Press

Arendt, H. 1966 (1951). The Origins of Totalitarianism. New York: Harcourt Brace \& Co.

Arendt, H. 1968 (1961). Between Past and Future. New York: Viking Press

Arendt, H. 1970. On Violence. New York: Harcourt Brace \& World

Arendt, H. 1973a (1963). On Revolution. Harmondsworth: Penguin

Arendt, H. 1973b (1972). Crises of the Republic. Harmondsworth: Penguin 
Arendt, H. 1973c (1955). Men in Dark Times. Harmondsworth: Penguin

Arendt, H. 1978. The Life of the Mind: Vol. 1 \& 2. London: Secker \& Warburg

Arendt, H. 1994. Essays in Understanding, 1930-54 (ed. J. Kohn). New York: Harcourt Brace \& Co.

Aristoteles. 1976. The Nicomachean Ethics (transl. J. Thomson). Harmondsworth: Penguin

Bellah, R. e.a. 1985. Habits of the Heart. Individualism and Commitment in American Life. Berkeley: Univ. of California Press

Connolly, W. 1987. Politics and Ambiguity. Madison: Univ. of Wisconsin Press

Connolly, W. 1988. Political Theory and Modernity. Oxford: Blackwell

Connolly, W. 1991. Identity|Difference. Democratic negotiations of political paradox. Ithaca/London: Cornell Univ. Press

Connolly, W. 1995. The Ethos of Pluralization. Minneapolis: Univ. of Minnesota Press

De Dijn, H. 1993. Hoe overleven we de vrijheid? Modernisme, postmodernisme en het mystiek lichaam. Kapellen: Pelckmans

De Dijn, H. 1999. De herontdekking van de ziel. Voor een volwaardige kwaliteitszorg. Nijmegen: Valkhof Pers

Dossa, S. 1989. The Public Realm and the Public Self. The Political Theory of Hannah Arendt. Waterloo: Wilfrid Laurier Univ. Press

Hill, M. (ed.) 1979. Hannah Arendt: The Recovery of the Public World. New York: St. Martin's Press

Hinchman, L \& Hinchman, S. (eds.) 1994. Hannah Arendt: Critical Essays. Albany: State Univ. of New York Press

Honig, B. 1988. Arendt, Identity, Difference. Political Theory 16/1:77-98

Honig, B. 1993. Political Theory and the Displacement of Politics. Ithaca: Cornell Univ. Press

Kateb, G. 1984. Hannah Arendt: Politics, Conscience, Evil. Totowa: Rowman \& Allenheld

Kohn, J. \& May, L. (eds.) 1996. Hannah Arendt - Twenty Years Later. Cambridge, Ma.: MIT Press

Lasch, C. 1980. The Culture of Narcissism. London: Abacus

Lasch, C. 1985. The Minimal Self. Psychic survival in troubled times. London: Picador

Lasch, C. 1991. The True and Only Heaven. Progress and its Critics. New York: Norton

MacIntyre, A. 1981. After Virtue: A Study in Moral Theory. London: Duckworth

Passerin d'Entrèves, M. 1994. The Political Philosophy of Hannah Arendt. New York: Routledge

Schoeman, M. 2004. Generositeit en Lewenskuns. Grondtrekke van 'n post-Nietzscheaanse etiek. Pretoria: Fragmente Uitgewers

Sennett, R. 2002 (1976). The Fall of Public Man. London: Penguin Books

Taylor, C. 1975. Hegel. Cambridge: Cambridge Univ. Press 
Villa, D. 1992. Beyond Good and Evil: Arendt, Nietzsche, and the Aesthetisization of Political Action. Political Theory 20:274-308

Villa, D. 1996. Arendt and Heidegger. The fate of the political. Princeton: Princeton Univ. Press

Villa, D. 1999. Politics, Philosophy, Terror. Essays on the thought of Hannah Arendt. Princeton: Princeton Univ. Press

Villa, D. (ed.) 2000. The Cambridge Companion to Hannah Arendt. Cambridge: Cambridge Univ. Press

Visker, R. 2000. The Public and the Private. Reply to Taminiaux. (Unpublished paper) 
Copyright of South African Journal of Philosophy is the property of Philosophical Society of Southern Africa (PSSA) and its content may not be copied or emailed to multiple sites or posted to a listserv without the copyright holder's express written permission. However, users may print. download, or email articles for individual use. 